\title{
IMPROVING STUDENTS' WRITING ABILITY BY USING PERSONAL PHOTOGRAPH OF SEVENTH YEAR AT SMPN 4 BANYUWANGI IN THE 2014/2015 ACADEMIC YEAR
}

\author{
Asmiyati Ningsih,
}

English Education Departement, PGRI University of Banyuwangi

Received : Monday, October 15, 2018

Revised : Friday, October 19, 2018

Accepted : Monday, October 29, 2018

\section{Abstract}

English plays important role for all aspects because the development of science and technology is mostly transferred through it. English is taught in the forms of speaking, writing, listening and reading integrative. Among the four language skills, writing is considered to be most difficult to master, because it needs continues thinking process for expressing ideas, feelings, or thought in a piece of paper.

The research was carried out at SMP 4 Banyuwangi. The subjects of the research are the students of the seventh grade A student. The research method was classroom action research. This classroom action research had two cycles which consisted of four main stages in each cycle. They are preparation, implementation, observation, and reflection of the action. In each cycle, the teaching and learning process were conducted into three meetings which include two meetings of applying method and one meeting for the writing test. In the first cycle the researcher used personal photograph as a media in teaching descriptive text, researcher asked students to describe their personality and their families in the class based on the example that had been given by the researcher. In the second cycle, researcher asked students to describe their friend in photos that was brought by the student in group.

The result of preliminary study showed that the main score of the students' writing descriptive paragraph result was low $(M=49,78)$. Meanwhile, the standard minimum passing level score in this school is 75 . In the first cycle on Monday, 11 st May until 16th Ma y 2015 in th re e m e e ting s, the re se a r c h e r found the mean of the score of the students' writing was 74,83 with the total score 2694. In the second cycle on Monday 18th May until 25th May 2015 , the researcher found the mean of the score of the students' writing was 79,72 with the total score 2870. Based on that fact, the result of the research shows that the students improve their ability in writing descriptive text by using personal photograph as the media. They are better in writing and arranging the sentences than in pretest.

The objectives of the research are firstly to know the improvement of students' ability in writing descriptive paragraph. The second is to find out how the use of personal photograph to improve the students' writing descriptive paragraph 


\section{A. Introduction}

Writing is the one that be the most difficult skill to learn. The students think it is difficult because they are afraid to make errors in their writing such as errors in spelling, grammar, punctuation, and wrong in choosing vocabulary. Then they also difficult in organizing their ideas in paragraph unity. It includes the ability to express the student's opinion or thoughts clearly and effectively. Ratnasari (2004) as cited by Sa'diyah (2011:164) stated that writing skill can be achieved by the students if they know some techniques of writing such as how to gathering the ideas about they will write on, how to sequence the sentences, how to organize them chronologically and coherently, and how to review and finally revise the composition until the writing is good stated

In teaching and learning process of writing, the teacher needs a media to help them conduct the study. The Media can make the teaching and learning process successful and run well. There are many that can be taken when the teacher uses a media in supporting the teaching of writing. The one of them is making the students easier to write a paragraph unity because they have understood what they should write on. With the media the students will interest in writing process. The teacher must be smart to choose the correct media that suitable to be used in teaching and learning process because of there are many media to teach the students.

Based on the standard competency in the syllabus of the second grade in Junior High School is to express meaning in the functional text and the very simple short essay in the descriptive and procedure form to interact with their closed environment (Depdiknas 2013). More specific in basic competencies, the students are expected to express meaning and rhetorical steps of very simple essays using written language accurately, fluently, and appropriately in daily life contexts in the descriptive and procedure form.

Based on the objectives of the study indicates that the students are expected to be able to write simple paragraphs such as descriptive, narrative, report, recount, and procedure text. In this case, researcher uses the descriptive text to help the students improve their writing ability. Descriptive text is the text which describes something, situation, someone, and etc. or write about the way places, persons, or things appear. In learning descriptive text, students may have difficulties in learning it. Students confused to write the descriptive paragraphalthough they know the topic which has been given by the teacher. They are confused to write their idea about the topic to make a paragraph unity.

The researcher investigated the learners' proficiency in descriptive writing paragraph accurately, fluently and acceptable in the environment. The researcher conducted the study to seventh grades of SMPN 4 Banyuwangi. The researcher gave the writing test. The test is the students must make descriptive paragraph depend on the pictures that was prepared by the teacher. The teacher gave 45 minutes for the students to do it. The result showed that the students' writing ability was unsatisfactory. Most of the students could not achieve the minimum 
passing criterion is 75. Based on the result, the students had problem in gathering and improve their ideas, they could not organize their writing, they used incorrectly in the grammatical and the vocabulary. It makes they lose motivation in writing. Among those problems, the major problems are the students' weaknesses in their writing were lack of ideas and poor ability to organize them.

Based on the problems mentioned above, the teacher chooses the media to help the students upgrade their writing ability. In this case, the teacher chooses the personal photograph to be media in teaching and learning process. The personal photograph is the authentic material that the students always know and do in their daily activities. In this modern era, most of the students have social media and they always take pictures and upload them in to their social media. It is the real conditions that happen in the students' activities. Besides that, they also have many personal photographs that have beautiful moment and important meaning in their lives. It can be the authentic material that can help the students in teaching and learning writing.

\section{Statement of the Problems}

Based on the background of the study which has been discussed, the research problem is how can personal photograph improve the seventh year students' writing descriptive paragraph ability at SMPN 4 Banyuwangi in the 2014/2015 Academic Year?

\section{Objective of the Study}

In relation to the problems which have been stated above, the objective of the study is to investigate and to improve the students' writing descriptive paragraph ability by using personal photograph the seventh year students at SMPN 4 Banyuwangi.

\section{The Significance of the Study}

The result of conducting this study hopefully will give contribution to English teaching and learning, they are:

a. Students

The result of this study may motivate the students to improve their interest in writing, especially in writing descriptive text.

b. Teacher

The teacher will make a right decision to use some media or techniques for supporting teaching and learning process, especially to use personal photograph or pictures in improving the students' writing ability.

c. Further Researcher

The further researcher will use this research result as the reference to conduct the research in different method research.

\section{The Scope and Limitation of the Study}

The researcher conducted this classroom action research at SMPN 4 Banyuwangi of seventh year the subject of this research is 35 students of VII A, registered in second semester of 2014-2015 academic years. It is very important to limit the scope of analysis to get the relevant data. In this proposal focuses on using personal 
photograph to improve students' writing descriptive paragraph ability. The researcher attempt analyze the use of personal photograph as media to improve the students' writing ability and the teacher's way to evaluate the students' writing ability in writing descriptive paragraph.

\section{Definition of Keyterms}

a. Improving

It means the way to make the students' writing ability become well than before.

b. Writing

Writing is regarded as a productive skill especially in writing descriptive paragraph. It aims at assisting students in expressing their idea written.

c. Descriptive Paragraph

It is part of factual genre which describes a person in the students' family.

d. Personal Paragraph

It is the media personal photograph to be the way to help the students be easier in making descriptive paragraph writing.

\section{B. The General Concept of Writing}

Writing is one of language skills and productive skill that will be learned by students in junior high school, senior high school, and University. (Handini and Saragih, 2013: 5) state that the most grateful communication tools that used to share and create our thoughts and ideas in our life is writing. It can help people to remember all of the information because most of the people tend to remember written communication than oral. Hence, the students will be able to express their ideas and feeling by English writing. (Taselin in Cahyono, B.Y .2010: 103) writing skill make the students increase their language and reasoning skill as well.

Learning writing as a foreign language is not easy as learning native language. They will meet all of learning problems dealing vocabulary, organization, content, and grammar or structure. Many English students think of writing as the fact of picking up a pencil and forming a letters either by printing or writing them in cursive they could think about the fact composing a piece of text. There are two main types of writing. First, writing which in each character is picture of an object or media, called picture writing or ideographic writing. Second, writing in which each character represents speech sound called alphabetic writing. Most of languages, including English and Indonesian use alphabetic writing to represent their speech sound which is used by public in books, paper, magazines, and writing letters.

Based on the statement above, writing is one of the language skills which have combination of process and productive skill that can be used to preserve thoughts, ideas, and speech sounds. All of them will be presented in manner that is polished and comprehensible to the readers. Therefore, writing is the way of thinking or sending message from the writer 
to the reader which becomes the part of language or language skills and it also means communication.

\section{The Characteristic of Good Writing}

Harmer (2004: 22-24) said that a good writing is a product of careful thinking. There are several characteristic of a good writing. They are cohesive structure, coherent structure and the last correct spelling and grammar.

a. Cohesive structure

It means that the used of appropriate grammatical patterns; substitutions, elliptical construction, preposition, conjunction to relate among the clauses within paragraphs, and references. The writer can use various grammatical devices to help the reader understand what is being referred to at all times, even when words are left out or pronouns are substituted for nouns.

b. Coherent structure

It means that writing have organizational scheme or outline. The text to have coherence needs to have some kinds of internal logic which the reader can follow with or without the use of prominent cohesive devices.

c. Correct spelling and grammar

Strong grammatically skills lend credibility to the writing. They also enhance the readability of the documents, since misspelled words and grammatical errors distract readers from the message, Widarso (1992:12).

Grammatical errors, there are some errors that always done by the students. The first grammatical error is comma splices. Comma splices are independent clauses joined by a comma. The second is run-on sentences which are independent clauses joined together without punctuation or a coordinating conjunction. And then the last is sentences fragments which are incomplete sentence. To be complete, a sentence must have a subject and a verb, and it must make a sense.

Jeremy Harmer (2004:39) said that a good writer always has a purpose in mind and construct their writing with a view to achieving that purpose. There are three main categories of teach which it worth considering.

Based on the purposes above, important for the writers to know how to make the readers understand what information being delivered. Also a good writer should make readers interested, the last is a good writer should persuade readers in their text.

\section{Process in Writing}

Writing process is the stages a writer produces something in its final written form. This process, of course, is affected by the content (subject matter) of the writing, the type of the writing (shopping list, letter, essays, report, thesis, or etc.). The process of writing make framework of writing well and easily. Generally the writing process 
consists of three stages, they are prewriting, drafting, editing and publishing.

a. Prewriting

This stage is the most productive way to begin the writing. In this case, it is very important to collect thoughts and ideas on paper without pressure of structuring into its final form. Harmer (2004: 4) argues that in planning stage, the writers have to think about three main issues. First is the purpose of their writing. It will influence not only the type of the text they wish to produce, but also the language they use, and the information they choose to include. Second is the thinking of the audience. And third, must know how to consider the content structure of the piece. It shows the facts, ideas, or arguments which they have decided to include. Taselin in Cahyono B.Y(2010: 108) states that there are several ways to warm up before writing, the first is Brainstorming. It is a quick way to generate a lot of ideas on a subject. The purpose is to make a list as many ideas as possible without worrying about how to use them. They can include words, phrases, sentences, or even question. To brainstorm, there are some steps: first, begin with a broad topic, second, write down as many ideas about the topic, third, add more items to the list by answering the questions what, how, when, where, why, and who, fourth, group similar items on the list together, and then the last cross out items that do not belong.

The second of ways to warm up before writing is clustering is another prewriting technique. It is a visual way of showing how ideas are connected using circles and lines. In other words, clustering is an activity of drawing the ideas. To cluster, there are some steps: firstly, write the topic in the center of a blank piece of paper and draw a circle around it, secondly, write any ideas that come into mind about the topic in circles around the main circle, thirdly, connect these ideas to the center word with a line,

Fourthly, think about each of new ideas, write more related ideas in circles near the new ideas, and then connect them and the last repeat this process until the ideas run out.

b. Drafting

In the drafting stage, it must focus in put the ideas in some kind of order and envision a potential shape for the work that the students will produce: a beginning, a middle, and an end. Hence, refer to the first version of a piece of writing as a draft. As the processes proceed of editing, all of the concept of writing can be produced into the final version.

When writing a paragraph, remember to: first, begin with a topic sentence that states the main idea, next, include several sentences that support the main idea, third, stick to the topic do not include information that does not directly support the main idea, fourth, arrange the sentences so that the order of 
ideas makes sense, and the last use signal words to help the reader understand how the ideas in paragraph are connected.

c. Editing

After drafting, the next step is revising. It is because to revise their writing is important if they want to be a professional writer. After completing the first draft, a writer must look for ways to improve it. This step is called revising. When revising paragraph, we can do the following: 1) Add new ideas to support the topic, 2) Cross out sentences that do not support the topic, and 3) Change the order of the sentences.

From the writing process above, it must to conclude that writing is a process of creating, organizing, writing and revising. In the first step of the process is creating ideas. In the second step is organizing the ideas. In the third step is writing a rough draft. In the final step is editing a rough draft and making revisions. Harmer (2004: 5) argue that reflecting and revising are often helped by other readers who comment and making suggestions. Another reader's reaction to a piece of writing will help the author to make appropriate revisions.

d. Publishing

After the process of editing their draft, making the changes they consider to be necessary, they produce their final version. This may look considerably different from both the original plan and draft, because things have changed in the editing process. But now, the result of written text is ready to send to its intended audience.

\section{Teaching Writing for Junior High School}

Writing as one of the four language skills has always formed part of the syllabus in the teaching of English. Writing has always been used as a means of reinforcing language that has been taught Stated by Harmer (2004: 31 ). In other words, writing is a good way for students who learn English. They can put their ideas on paper by paying attention on grammar rule and vocabulary. When writing, students need more time to think. Teacher asks students to focus on the accurate language used and what ideas they will write. It can provoke their language development.

Teaching writing for Junior High School is not an easy job, because the range of age of Junior High School students varies between thirteen to fifteen

years old. They can be named teenagers. Teens are in between childhood and adulthood, so it is the period of transition and growing. In this period, they will experience the confusion, selfconsciousness, and changing bodies and minds. They will be very sensitive to how others perceive their changing physical and emotional selves along with their mental capabilities. One of the most important concerns of the secondary school teacher is to keep self-esteem high by; first, Avoiding embarrassment of students at all 
costs. Second, affirming each person's talents and strengths and then third allowing mistakes and other errors to be accepted, fourth de-emphasizing competition between classmates and then the last fifth encouraging small-group work where risks can be taken more easily by a teen.

Based on the statement above, the researcher concludes that the teacher's role is very needed to motivate students in teaching learning process while students in a transition period. Therefore, they will have good discipline and responsibility, if a teacher encourages their students to learn in writing in the target language. Therefore, teens are a period of change, new experiences learning, and instability life. Teacher should provide them with opportunities to explore and experiment in a stable and supportive atmosphere. Teacher's job is to provoke intellectual activity by helping them be aware of constructing idea, then let them to resolve it by themselves even though still with the teacher's guidance.

Based on the statement above, at the Junior High School level, students can start writing short texts consisting of several sentences. When writing short paragraphs in this way, the students learn to relate one sentence to the next by connecting the sentences using pronouns and conjunctions. Students should be introduced to this type of writing activity in steps. First, they can be given picture prompts. By writing simple sentences to describe the pictures, they can write a simple short paragraph or story

\section{The nature of Genre}

Genre is one of the most important and influential concept in language education. Genre can be defined as a culturally specific text - type which result from using language (written or spoken) to (help) accomplish something. So genres are cultural specific and have associated with: particular purposes, particular stages and particular linguistic features.

Every genre has communicative purpose, generic structure and lexicon grammatical features. Students are taught these features and a language for talking about the language in the context of learning how these features contribute to overall meaning of text they are writing. The meaning of the genre intended is that students are able to understand the concept and they would be able to identify a kind of texts that students will have to writ. In this case, the students will know how to represent the use of language to respond the situations. (L. Gerrot and P. Wignell 1995: 1992 cited by Hami Widodo $2011: 14)$ stated that there are kinds of the text which is studied in Junior High school, it is recount, narrative, descriptive, procedure and report.

a. Recount

Recount is a piece of text that retells events for the purpose of informing or entertaining. 
b. Report

Report is a piece of text that describes the way things are, with reference to arrange of natural, man-made social phenomena in our environment.

c. Narrative

Narrative is a piece of text that amuses, entertains and deals with actual or vicarious experience in different ways. Narratives deal with problematic events which lead to a crisis or turning point of some kinds, which in turn finds a resolution.

d. Procedure

Procedure is a piece of text that describes how something is accomplished through a sequence of actions or steps.

e. Description

Description is piece of text that describes a particular person, place, or thing. (Susanto, 2011:23) said that descriptive text is the text that describes people, places, animal etc. a descriptive text is usually used to create and to develop the characteristic of a person and why he or she is so special that the reader can create a vivid picture of character.

The key to writing a good description is to use details that help the reader imagine the person the students are describing, so when the students describe what a person looks like, the students write about physical characteristics such as height, weight, and hair color. There are two keys to writing good description. First key is to use space order, and the second key is to use specific detail. In space order, students might describe something from top to bottom or from left to right.

The second key to writing good description is to use specific details. When students describe something, they paint a picture with words. The goal is to make the reader see what they have describe. The way to do this is to use many specific details, specific means exact, precise. Karen Blanchard and Christina Root (2003:70) stated that the more specific they can do, make the reader can see what they are describing.

The descriptive writing will be good if the writer use the generic structure correctly. The structure of descriptive text follows some particular stages, the beginning, middle, and last part of the text. Pardiyono cited by Hami Widodo (2011:18) the generic structure of descriptive text is shown in the following

table 01: The Generic Structure of Descriptive Text

\section{\begin{tabular}{l|l}
\hline Generic & Structure Function
\end{tabular}}

\begin{tabular}{l|l} 
Identification & - It is a statement or a short
\end{tabular} paragraph that identifies the object that is going to be described.

- It is usually interesting and able to provoke the readers to b be eager to read the text. 
- It may consist of one of

- several paragraphs. This part is used to give sufficient description about the object as mentioned in the identification part.

- The description of the object can be done according to different angles, such as size, length, strength, color, height, condition of the location, weather, qualities, shape, etc.

So, the criteria of the words and sentences that always used in descriptive text must be known because it makes the writer easier in making descriptive paragraph.

\section{The Nature of media}

Media are means of communication and source of information that can be in various forms such as video/audio recordings, television, diagrams, printed materials, real objects, computer programs, instructors and etc. All of the media is categorized as instructional media because they provide messages with an instructional purpose that is to facilitate communication in the learning process

There are some media in teaching and learning process; audio, visual and audio visual (Ruis et al, 2009:10). First, audio is media that only rely on the sense of hearing/ listening. The examples of audio media are gramophone, open real tapes, cassette tapes, compact disc, radio etc. The second media is visual; visual is media which involve the senses of sight. There are two types of the message are delivered in a visual medium; verbal (in the form of words) and non-verbal (in the form of symbols) message. The examples of visual media are picture, photos, graphs, diagrams, charts and maps. The last kind is audio visual, visual audio which equipped with sound and images in a single unit. The examples are movie, television and video.

The one of media that very useful in teaching descriptive text is visual media. Many kinds of visual media, there are picture, graphs, diagrams, charts and maps. Picture in this classroom can represent situation which would be impossible to create in any other way. Many actions can be demonstrated in a classroom, many objects can be brought into the classroom like toys, tools, clocks, etc. Picture is one of the varieties of teaching aids which is used to explain language meaning and construction, engage students in a topic, or as the basis of a whole activity. Harmer (2011: 134) argues in teaching writing, teachers can use pictures - whether drawn, taken from books, newspaper and magazine, or photographs to facilitate learning.

From the definition above, it can be concluded that picture is one of the media in teaching learning process to support the presentation of the material by emphasizing the students visual sense 
that can be used to motivate and increase the students interest in teaching and learning process. According Harmer (2011: 136-137) In general, picture can be divided into several types, namely: the first flashcard, It is a small card which we can hold up for students to see. Flashcard is particularly useful for "drilling" grammar items, for cueing different sentences, or practicing vocabulary. The second large wall picture, it is big enough for everyone to see detail. Sometime teachers use large wall pictures when pointing to detail of a picture to elicit response. The third Cue card, it is small card which students use in pairs or group work. Teachers put students in pair of groups and give them some cards so that when a student picks up the top cue card in a pile he or she will say a sentence that the card suggests. And the fourth photograph or illustration, It is a photo or an image that depicts a situation or people in action. The teacher uses it to make the situation or the action clear. Photograph can be found in the book, newspaper, magazine, and now photograph and now photograph already very familiar in daily lives. Many people capture beautiful moments and make them in the form of photographs.

Photograph is worth a thousand words through which a complex idea can be conveyed with just a single still image. Pictures make it possible to absorb large amounts of data quickly. Using photographs for explaining complex phenomena is one of the teaching aids of modern education system all over the world. As the world is changing day by day so are the methods of instructions as the modern curriculum requires conceptual elaborations. Visual aids have the tendency to materialize the thoughts of students in the form of graphics to give thoughts a concrete frame of reference. Use of photographs is important for students because they are more likely to believe findings when the findings are paired with colored images describing complex situations during learning as opposed to other representational data such as complex book text. In addition, a photograph captured images or photography. Not only as the picture but also photograph is an effective visual media because it can visualize objects with more concrete, more realistic and more accurate. Pictures can transcend time and space. When students pay attention to a picture, they will be encouraged to talk more; interact well with the drawings, as well as with each other; make connections between paradoxes and build new ideas.

\section{The Procedure of Using Personal Photograph in Descriptive Text}

Using instructional media can stimulate the students because there are many benefits in using it. Latuheru (1998 cited in Sa'diyah 2011:166). Media can be used to be a stimulus for the students to find many ideas in their writing. In this case, the teacher must be smart to choose the media in teaching learning process. There are so many media that can be used in teaching such as video, songs, pictures, personal photograph, etc. personal photograph is the one of media that is easy to get. In this era some of people always capture the 
moment in their live. Personal photograph can be considered as teaching descriptive writing. It makes the students will be easier in writing process. To use the personal photograph. The teacher conducts it through three phase stages: Pre writing, Drafting, and Editing.
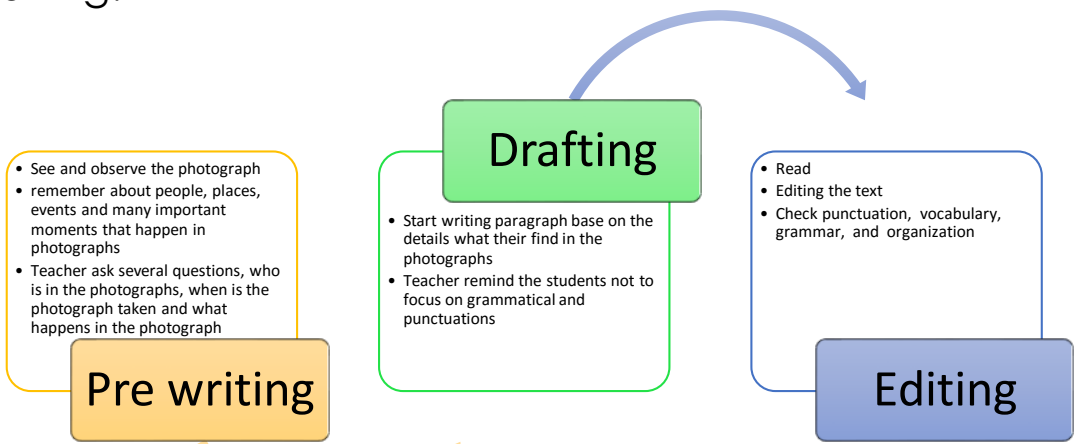

\section{The Positive effects of Using Personal Photograph on the Students' Descriptive Writing}

Steven (2004: 2) argues that the students will interested in the writing process when they can write about the topics that relating directly with their lives.

The use of personal photograph causes the positive effects for the students in the steps of writing.

- the personal
photograph make
the students easy
to find a good
ideas to write the
descriptive writing

- Students will be
easier to draft
their descriptive
writing.

- 3 Photograph will
recall their
memories
concerning to
detail and
moments when it
was taken

In conclusion, the personal photograph has many positive effects for the students in descriptive writing. The students will be easier to find the ideas in write the descriptive writing and they will not difficult in drafting activities. After that, they will more enthusiasm in the learning process, they have interested in write a descriptive writing and they will have a good attention in the class. So, using the personal photograph is very appropriate to be used in the teaching and learning process to improve the students' descriptive writing

\section{Previous Study}

There are two previous researches that are used by the researcher; they are the previous research that was conducted by Tri Yuliani (2007) and Ulin Ni'mah (2012).

The Use of Picture as Media in Writing a Descriptive Text at SMP N 1 
Taruh Tegal in the academic years of 2006/2007 that was conducted by Tri Yuliani explained that using picture as a media in teaching descriptive text is very helpful in producing the words or sentences. The students can see something through picture which gives imagination for students to describe something or place, so they are able to choose the appropriate words according to the description based on the picture.

The similarities between her research and writer are that this research focused on writing descriptive text and the approach used classroom action research and the differences between the previous research and the present research was about the implementation of the personal photograph of the students. This research used the reality that happened in the students' lives. Then, research entitled The Effectiveness of Using Basic Questioning with Picture to Improve the Students' Descriptive Writing Skill of the seventh grade at SMPN 31 Semarang in the 2011/2012 in the Academic Year by Ulin Ni'mah. The objective of her research was to find out the effectiveness of using basic questioning with the picture as media in improving the students' descriptive writing skill. The result showed that the use of the strategy by using picture as the media very useful in teaching writing descriptive text. It because the enthusiastic and motivated from the students in writing activity. Her thesis had similarities with this thesis. The first, it is similar in the skill and the media that used in the research. The second, the objective of the research which was want to know the improvement of the students' writing descriptive paragraph by using pictures and the last the result of the research showed that there was improvement of the students' descriptive writing ability. But, the differences between Ulin Ni'mah's thesis with this thesis are the use of technique and method.

\section{Research Method}

this study is classroom action research which is focuses on a particular group of the students in a certain classroom. The objective of this action research is to investigate and to find out the improvement of students' writing descriptive paragraph ability in generic structure and academic writing by using personal photograph of seventh year students at SMPN 4 Banyuwangi in 2014/2015 Academic Year.

The research design is collaborative action research which focuses on a particular group of the students in a certain classroom. It is most rationally empowering when undertaken by participants collaboratively, though it is often undertaken by individuals, and sometimes in cooperation with 'outsiders'. In this research, the researcher acts as a teacher who will prepare the activities such as designing a plan of action, observing and making test for the students. The researcher directly works together with one of the English teacher to help conducting the research as well as to cope with the student problem investigate and note the student actions. There are four activities in this part: planning, implementation/acting, observation and reflecting. 
The research respondent was population of the students in the $7^{\text {th }}$ grade of SMP 4 Banyuwangi Class A 2014/2015. it consisted 35 students, 15 males and 20 females.

Writing test delivered as the primary data collection, and the first test was preliminary study and the second test was the achievement test.

the writing test materials consist of the content mastery, organization mastery, vocabulary mastery, grammar mastery, mechanic mastery. The detail of the test score as follow:

\begin{tabular}{|l|l|l|}
\hline NO & ELEMENT OF WRITING & SCORE \\
\hline 1 & The content mastery & $20 \%$ \\
\hline 2 & The organization mastery & $25 \%$ \\
\hline 3 & The vocabulary mastery & $20 \%$ \\
\hline 4 & The grammar mastery & $25 \%$ \\
\hline 5 & The mechanic mastery & $10 \%$ \\
\hline TOTAL SCORE & $100 \%$ \\
\hline
\end{tabular}

Matrix assessment for students writing in Descriptive Text

\begin{tabular}{l|l|l}
\hline Score & Value & \multicolumn{1}{|c}{ Description } \\
\hline $80-100$ & Excellent & $\begin{array}{l}\text { Describe all of the parts, qualities, } \\
\text { and characteristics completely } \\
\text { Describe parts, qualities, and } \\
\text { characteristics. Somewhat choppy } \\
\text { loosely }\end{array}$ \\
\hline $40-59$ & Fair & $\begin{array}{l}\text { Fairly describe parts, qualities, and } \\
\text { characteristics. Some are missing } \\
\text { Poorly describe; many parts, } \\
\text { qualities, and characteristics are } \\
\text { missing }\end{array}$ \\
\hline $0-19$ & Very Poor & $\begin{array}{l}\text { Does not describe the parts, } \\
\text { qualities and } \\
\text { characteristics anymore }\end{array}$ \\
\hline
\end{tabular}

The result of the writing test analyzed by following procedures:

a. The researcher computes the student's structure score in their ability to write descriptive text.

b. The researcher put those score into a table. It's supposed to know the values writing ability score.

c. After knowing the values, the researcher analyzed by data quantitative.

d.

The quantitative formula for analyzed the score is:

$$
\sum n=\frac{n}{N} \times 100 \%
$$

Formula Description:

$\sum n=$ percentage of the students' writing test

$n=$ score of the students' writing test

$\mathrm{N}=$ total the highest score 
The result of the quantitative analysis consulted to the following table:

\begin{tabular}{|l|l|}
\hline Score level & Category \\
\hline $86-10$ & Excellent \\
$71-80$ & Good \\
$56-70$ & Enough \\
$41-55$ & Poor \\
$26-40$ & Bad \\
$<25$ & Very Bad \\
\hline
\end{tabular}

\section{Result and Data Presentation}

\section{The Preliminary Study}

The preliminary study stated from observation to find the problem. It was done on May 9th, 2015. As results of the preliminary study, the researcher identified a problem in students writing ability. They had problem in writing descriptive text, especially in deliver their ideas and language features of the text.

The average of reading comprehension score in the preliminary test was 49,78 that consist of 10 sentences to write descriptive text. The respondents from preliminary test were 36 students, 16 males and 20 females. The result of test showed that the students' average score was lower than the Standard Minimum of the school where it was used as the criteria of success in this research. The average score for the criteria of success in this research is 75 based on Standard Minimum of the school.

\section{First Cycle}

The first cycle was conducted on May 11st, 2015 until May 16th, 2015 in three meetings; two meetings were for giving treatment and one meeting for

implementing writing test by using personal photograph. The test was held on Wednesday, May 16th, 2015. The students' activity was writing descriptive paragraph that consist of 10 sentences about their personality and their families. Before the students presented writing test, the researcher explained the material first. It was about describing person. After giving the explanation about it, the students did the writing test.

Based on the mean of the students' score, it can be said that the students' achievement on writing ability had improved, but the problem was not solved yet. It is because the researcher couldn't reach the criteria of success where there must be $75 \%$ of the students' score were up to 75 based on the Standard Minimum Score in SMPN 4 Banyuwangi. Therefore, the researcher made a revision of learning strategy for the next cycle.

\section{Second Cycle}

The second cycle was conducted on May 18th, 20th, and 25th, 2015 in three meetings. Two meetings for giving treatment and one meeting for implementing writing test by using personal photograph as a media. The second cycle was done because the 
students' score of descriptive writing text still low and there were many aspects that should be improved. The total of students' score was 2694 and the number of the students who took the test was 36 students. So the mean of students' score was 74.83. Based on the result in first cycle, the researcher decided the better way to make the approach more effective in teaching learning process. There were many students have difficulties in writing descriptive text, it is because writing English is not their habit. The researcher made a planning based on the difficulties in the previous cycle in teaching writing descriptive text. Therefore, the researcher revised the plan to improve the students' achievement in writing ability.

Based on the data above, the problem could be solved because the researcher could reach the criteria of success where there must be $75 \%$ of the students got score 75 the Standard Minimum score in SMPN 4 Banyuwangi.

\section{Discussion}

The result of data analysis showed that personal photograph positively contributed to the students' writing descriptive paragraph achievement at SMPN 4 Banyuwangi in the 2014/2015 Academic Year. This could be seen from the resultof the writing test in the seventh grade that they had improved in writing descriptive paragraph.

Based on the previous research, the purpose of this research is to know whether there is improvement of students' ability in writing descriptive paragraph or no after being taught by using personal photograph as the media. In this study, the researcher found that there was improvement to the student's ability in writing descriptive paragraph through personal photograph. It could be seen from the student's ability level in writing descriptive paragraph from the first test (pre-test), the second test (at the end of cycle 1), and the third test (at the end cycle 2). The result of the preliminary of the students' writing test is low. The mean of the students' writing test is 49.78. It means that the students have problems in writing. After recognizing the students' problems in writing, the researcher would explore ways that personal photograph can become an aid in teaching writing descriptive paragraph.

The criteria of success have been fulfilled on the second cycle. It means teaching writing especially descriptive text, is the use of personal photograph as the media is potentially applicable. There were things that the researcher found in the presents research. The understanding of the students was improved during the teaching and learning activity. It helps them to get idea by connected their real life with the material easily and made them easier to make a descriptive paragraph.

The mean of writing score during the actions, that of first cycle was 74,83 and 79.72 in second cycle. Those mean that the actions implemented in this research have given positive result in improving the students' descriptive text writing ability The first cycle, the 
researcher gave some explanation about descriptive text and explains how to use personal photograph in writing descriptive paragraph. The researcher also gave models how to identify the photos and how to make sentence based on the photos until they make a paragraph of descriptive text. From the first cycle, the researcher gave a writing test and the result of the test better than in preliminary test. The mean of the result on writing test in first cycle was 74.83 with total score 2694. The students' writing had improved but it did not reach the criteria of success where there must be $75 \%$ of the students' score were up to 75 based on the Standard Minimum Score in SMPN 4 Banyuwangi. Therefore, the researcher made a revision of learning strategy for the next cycle.

The second cycle, the researcher gave the explanation about descriptive text than the researcher makes a new strategy in teaching descriptive paragraph. The researcher asked the students to bring their personal photograph. After that, the researcher asked them to work in group and described about their friends' photos. The student's enthusiasts in did the tasks. From the second cycle, the mean of the result of the students' writing test was 79.72 with total score 2870. It means that the problem could be solved because the researcher could reach the criteria of success where there must be $75 \%$ of the students got score 75 the Standard Minimum score in SMPN 4 Banyuwangi.

From the above discussion, in line with the statement by (Wright 2002:86) that was cited by (Selly Silvia: 2014) states that pictures have many roles in teaching descriptive paragraph. It is very important in helping the students to retell experiences or understand something because they can represent place, object and people in the real lives. The result of the writing test in second cycle showed thatthe use of personal photograph can improve the students' writing descriptive paragraph of the seventh grade A students at SMPN 4 Banyuwangi in the 2014/2015 Academic Year.

Based on the analysis data, the researcher thought that this classroom action research should be ended up to the second cycle. Having learnt the research result, the researcher believes that the use of personal photograph as the media in teaching writing descriptive text can motivate the students to write simple sentences and can improve the students' writing ability.

\section{E. Conclusion}

Based on the result of data analysis, it can be concluded that the use of personal photograph as media in teaching and learning process can help the students to have relation between their real lives with the material taught especially descriptive text. It also helps the students to write simple sentences and develop them into good paragraph. Besides, it can stimulate the students more active in learning English, so that they can express their thought or ideas in the written form. In this research, the researcher also found the fact that the use of personal photograph can improve the students writing 
ability. It was proved by the increase of the seventh year students writing score from 74, 83 in first cycle and 79, 72 in second cycle

\section{F. Acknowledgement}

All Praise be to Allah, The Lord of the Worlds, The Almighty God for a precious life, health, longevity, help and guidance who has bestowed upon me in completing this Proposal. Peace is upon Muhammad SAW, the last messenger of Allah, and to all his families, companions, and followers.

During writing this thesis, there are a lot of people who have give great helps from the beginning phase of the research until it finished

Finally, the Researcher greatly hopes that this thesis will be useful for the reader or someone else who reads and thanks a lot of all your helps. God Bless you all.

\section{G. Reference}

Cahyani, H. \& Cahyono, B.Y. 2011. Best practices in the Teaching of English.

Malang: State University of Malang Press.

Cahyono, B.Y. 2010. The Teaching of English Language Skills and Language

Components. Malang:State University of Malang Press.

Darmadi, Hamid. 2011. Metode Penelitian Pendidikan. Bandung : Alfabeta. Handini, F. D and Saragih, A. 2013. Improving the Students' Achievement in

Writing Procedure Text ny Appliying Mind Mapping Technique.Indonesia: from http://jurnal.unimed.ac.id/2012/index.php/jelt/article/view/919

Hami, W. 2011. Improving Students' Ability in Writing Descriptive Text Through Wholesome Scattering Game. Semarang: Thesis Education Faculty Walisongo State Institute for Islamic Studies.

Harmer, J. 2004. How to Teach Writing. Malaysia:Associated Companies throughout the world. 
Hopkins, david. 2008. A Teacher's Guide to Classroom Action Reasearch. New York: Open university Press and Two Penn Plaza.

Nawawi, Muhammad Bagus. 2011. Improving Students' Writing Skill of Descriptive Text through Guided Questions. Thesis Faculty of Tarbiyah and Teachers Training Syarif Hidayatullah State Islamic University.

Ruis, Nuhung et al. 2009. Instructional Media. Jakarta:Ministri of National Education.

Sa'diyah, H. 2011. Improving Students' Ability in Writing Descriptive Texts through a Picture Series-Aided Learning Strategy. Lamongan, Indonesia: The English Teacher Vol. XL: 164-182. Retrieved from: www.melta.org.my/ET/2011/164_182_Halimatus.pdf (Accessed on March 1st, 2013)Steven, K. 2004. Using Personal Photographs to Spark Narrative Writing. Japan: The Internet TESL Journal, Vol. $X, \quad$ No. $10 . \quad$ Retrieved from: http://iteslj.org/Lessons/Ahola-PersonalPhotographs.html

Susanto, Nasih Iwan. 2011. Teaching English by Using Various Text Types: Writing Descriptive Texs Using Mind Mapping and Pictures. State University of Malang Press.

Widarso, Wishnubroto. 1993. Kiat Menulis Dalam Bahasa Inggris. Yogyakarta:Penerbit Kanisius (Anggota IKAPI). 